\title{
HOUSEHOLDS' WILLINGNESS TO DONATE FOR THE CONSERVATION AND MANAGEMENT OF THE AYER KEROH RECREATIONAL FOREST, MELAKA
}

\author{
FARAH HANIM MOHD SHARIF ${ }^{1}$, NITANAN KOSHY MATTHEW ${ }^{1,2 *}$ AND AHMAD SHUIB $^{3}$
}

${ }^{1}$ Department of Environment, Faculty of Forestry and Environment. ${ }^{2}$ Institute of Tropical Agriculture and Food Security (ITAFoS), Universiti Putra Malaysia, Serdang, Selangor, Malaysia. ${ }^{3}$ Faculty of Economics and Management, Universiti Putra Malaysia, 43400 UPM Serdang, Selangor, Malaysia.

*Corresponding author: nitanankoshy@upm.edu.my

Submitted final draft: 6 December 2020 Accepted: 26 January 2021

http://doi.org/10.46754/jssm.2021.10.012

\begin{abstract}
The benefits of recreational forests are not only for tourists, but also for households and residents living in the surroundings of the forests. Such benefits include supporting services, provisioning services, regulating services, and cultural services. Very limited studies have determined the value allotted by residents to a recreational forest, which in turn would result in incomplete decision-making processes concerning forest conservation. The aim of this study is to determine households' willingness to donate for the conservation and management of the Ayer Keroh Recreational Forest (AKRF) in Melaka. This study involved 300 households that were situated adjacent to the park. A total of 300 households were equally selected using stratified and systematic sampling in seven (7) small villages in Ayer Keroh. The findings from a Probit regression analysis revealed that the idea of enhancing conservation efforts, age, and income had a significant relationship with the willingness to donate. An estimation of the willingness to donate using the Double-Bound CVM amounted to RM17.74 per household per annum. The finding is important in order to understand the value allotted by the residents to the forest while, nevertheless, providing policy-relevant information for forest management and conservation purposes of a recreational forest.
\end{abstract}

Keywords: Conservation, households, management, recreational forest, Willingness To Donate (WTD).

\section{Introduction}

A forest is considered as one of the most productive ecosystems in the world because of its well-established ecological, economic, and cultural importance. Deforestation in tropical developing countries accounts for around 6\%$17 \%$ of global anthropogenic $\mathrm{CO}_{2}$ emissions (Bakaki \& Bernauer, 2016). The traditional and cultural aspects can be an important focus of attention for residents living near forests as they have higher levels of place attachment, as heritage forests not only offer ecosystem services, but also cultural value. Therefore, cultural bonding can be an important element in facilitating the environmental awareness of residents regarding forest conservation (Cheung $\&$ Hui, 2018). However, the public in tropical developing countrie, may not be willing to support (and pay for) forest conservation at the same levels that other studies on this issue have suggested (Bakaki \& Bernauer, 2016). Chen et al. (2017) investigated the attitudes and preferences of tourists on forest conservation in the Ryukyu Islands. The results indicated that visitors under 40 years of age, or those who were travelling with their families, were likely to donate more to the forest conservation fund, while respondents with higher household incomes or higher education levels tended not to donate more to the conservation of the village tree landscape. This study suggests that requests for donations or entrance tickets can be used to collect conservation funds for natural resources.

A recreational forest is usually characterised by unique topography features, such as waterfalls and scenic rivers of the forest (Rahman, 2007). Cubbage, et al. (2007) explained that recreational forests' benefits constitute a substantial part of the total economic value of forests in modern societies 
and are an increasingly important determinant in multi-functional forest management. These recreational forest activities should be concerned with the environment by minimising the negative impacts of destruction on the natural environment and provide opportunities for the local community to be involved in the socio-economic activities established within the area (Scheyvens, 1999). Moreover, recreational forests could also give economic value, which will increase national income. Quantifying the economic value of natural environment resources can show where goods and services are currently underpriced by the market. Other than generating revenues through entrance fees, the prices and market measures can also provide an effective means of regulating the demand for resources and of providing incentives for sustainable management (Yacob et al., 2009). Hence, an appropriate pricing policy for forests, per se, can be used as a tool, not only to achieve the successful and sustainable management of national parks, but also provide quality products and services at fair prices to visitors (Samdin, 2008).

The accretion demand in forest recreation infrastructure leads to crowded urban forest areas, making the provision of such infrastructure an ongoing challenge for urban forestry and leads to negative environmental impacts (Wilkes-Allemann et al., 2015). Natural resources, such as recreational forests, are public goods that could be used together to reap the benefits. In order to manage and maintain the forest conservation value at the Ayer Keroh Recreational Forest, the management needs a large amount of money, which is supported by funds from the state government.

Recreational forests provide various benefits to the households when this resource is utilised in a proper manner. The Ayer Keroh Recreational Forest (AKRF) area provides various benefits to the households. This includes ecosystem services that humans freely gain from properly functioning ecosystems like supporting services, provisioning services, regulating services, and cultural services.
Currently, the AKRF management lacks data on households' perceptions on the forest. Also, the benefits gained from the value allotted by the households to the recreational forest in Ayer Keroh remain unknown Norliza, (Deputy Director of Melaka Forestry Department), personal communication, 16 June 2019). This can be known by determining their willingness to donate (WTD) for conservation and management, per se.

Limited studies have identified the WTD of households for the conservation of natural resources, particularly in a recreational forest. More so, very few studies in Malaysia have used the CVM approach to identify the WTD of households. A study by Rahman (2007) has been carried out to know visitors' satisfaction levels towards recreational facilities and services in the AKRF, with a mean WTP value of RM 21.45 per year. Nevertheless, households are also one of the stakeholders that will benefit from recreational forests.

In terms of the methodological gap, so far, studies conducted in Malaysia on residents' values on the forest have been carried out using a Single-Bound method. However, the studies using a Double-Bound method are very limited and outdated. The accretion demand in forest recreation infrastructure is leading to crowded urban forest areas, making the provision of such infrastructure an ongoing challenge for urban forestry and leads to negative environmental impacts (Wilkes-Allemann, Pütz, \& Hirschi, 2015). Natural resources, such as recreational forests, are public goods thath could be used together to reap the benefits. In order to manage and maintain the forest conservation value at the Ayer Keroh Recreational Forest, the management needs a large amount of money that is supported by state government funds. In Malaysia, all the parks are largely funded by the government, either by the federal hgovernment, mainly the Forest Department and Ministry of Tourism, or the state government funds it through the State Development Fund and Forest Development Fund. Currently, out of 130 forest recreational areas, only less than 5 areas are managed by private operators (Ismail \& Rahman, 2010). 
At present, no entrance fee is charged to visitors. Households from the Ayer Keroh Recreational Forest will channel some funds to conserve and manage the resources available in the park for long-term sustainability. Furthermore, the donations may be used as an instrument to control the number of visitors to the forest, which will help prevent over-use and the accompanying ecological damage. An appropriate pricing policy in national parks can be used as a tool to not only achieve successful and sustainable management of the national parks, but also provide quality products and services (Samdin, 2008). At the same time, it allows for plans for the development of forests using the limited resources. Data for the study has been collected using a survey of a sample of the households near the recreational forest. The Contingent Valuation Method (CVM) was used to help in determining the forest conservation value to the households.

This study has proposed a preservation and conservation scheme for the Ayer Keroh Recreational Forest to maintain its current state and mitigate any degradation to its ecological system. The fund provided by this will aid conservation projects in sustaining the hill's natural capacity of flood mitigation, watershed protection, and habitats for animals, flora and fauna, and air pollution minimisation. The fund will also help maintain and upgrade basic infrastructures in the hill area. The WTD by the local communities towards this trust fund would reveal their appreciation of the forest's recreational and services values. These values can serve as valuable information for policymakers, especially the state government and local council, in approving future developmental projects in this area. Hence, the objective of this study is to access the households' willingness to donate for the conservation and management of one of the recreational forests in Malaysia.

\section{Literature Reviews}

The dichotomous choice contingent valuation method (DC-CVM) is a popular method in the field of contingent valuation. One reason is the explicit recommendation of a panel of experts led by Nobel Prize winners Kenneth Arrow and Robert Solos, appointed by the National Oceanic and Atmospheric Administration (NOAA) to assess the effectiveness of contingent valuation methods. Another reason is that people get their values for certain public goods by asking if they are willing to pay a price (bid) for the goods and they provide individuals with a simply answer of yes or no. This is like a market situation, each commodity has its own price, and consumers can choose whether to accept it or not.

Limited studies have used the dichotomous choice elicitation technique for the willingness to pay in the CVM with regards to residents.

\section{Malaysian Research Studies of the CVM for Households}

There are a smaller number of research studies of the contingent valuation method for households or local communities that are related to forest conservation and management. There are research studies in Malaysia that have used the CVM for local residents. Leong et al. (2005) conducted research to estimate the value of protecting a highland forest located in Peninsular Malaysia to local residents.

In this study, a total of 226 residents from an adjacent small town were randomly selected in a social survey. The study found that the conservation values of the area ranged between RM20 to RM27 per individual resident.

Besides that, there was a research by Abdullah et al. (2015) on estimating the conservation value of biodiversity in a national heritage site for the Forest Research Institute Malaysia (FRIM) using the CVM among residents in Selangor. This study involved 410 respondents from both urban and rural households of Selangor. It was found that the mean WTP values ranged from RM53.24 to RM67.22, which could contribute annual revenue ranging from RM66.3 million to RM83.8 million.

One study by Rafia Afroz (2011) was conducted for the evaluation of households' WTP to improve a solid waste management 
facility in Kuala Lumpur, Malaysia. This study involved 467 respondents. The study found that the average amount the households in Kuala Lumpur were willing to pay was a RM22 waste collection service charge per month, which was $1.7 \%$ of their income.

Besides that, other studies relating to the CVM for households included one by Bann (1999) who evaluated the biodiversity benefits of the mangroves of Johor. 300 households represented within the study area around the Benut mangrove area were randomly selected. The mean value of RM1.38 was taken as the lower-bound WTP and RM5.43 was taken as the upper-bound WTP.

Another local study was conducted using the CVM to value the WTP of households for solar energy in Kuala Lumpur, Malaysia (Afroz et al., 2019). A total of 400 families were questioned face to face. It was found that RM16 was the average WTP value per family, which was the mean value that would be paid as an additional charge OF electricity bill.

A study by Masahina et al. (2012) was carried out to estimate households' WTP for improving the air quality in the Klang Valley. This study was expected to minimise the problem of mismatch, which can be supplied by the government and what the public was willing to pay for. A total of 600 respondents were selected from six urban areas.

One of a few studies was undertaken to look at the WTP of fishermen for a conservation fee. Ramli, Samdin, and Ghani (2017) researched the case of the Matang Mangrove Forest Reserve in Perak, Malaysia with a WTP for conservation fees using the contingent valuation method. The objective of this study was to assess the economic value of the mangrove ecosystem, and whether it provided useful information for decisionmakers in their decision-making processes regarding land-use options. This study used the CVM of the Double-Bound choice, which estimated the willingness of mangrove direct users (fishermen) and non-direct users (tourists) to pay protection money. The respondents were selected through purpose sampling and there were 685 respondents in total: 385 tourists and 300 fishermen. The dependent variable was willingness to pay, and the socio-demographic variables were income, education, household size, and ethnicity. As a result, the intentions of the non-consumer direct users were significantly affected by ethnic origin, marital status, and income, while the intention of the consumer direct users was significantly affected by income and nationality. These measurements have been essential to assist policymakers in sustainable mangrove management to achieve sustainable development in Malaysia.

A study using the Single-Bound CVM was conducted by Kamaludin et al. (2013) on estimating consumers' WTP for water services improvement in the state of Kelantan, Malaysia. Insufficient funds to improve the water supply coverage in the state triggered the need to revalidate the current water tariff. The study involved 552 respondents who were randomly chosen from urban and rural areas in the state of Kelantan using the stratified random sampling. The logit regression analysis was conducted to identify the factors influencing consumer WTP. The proposed bid price, household income and household size were found to have significant relationship with the WTP. The mean WTP was estimated tp be $8.7 \%$ more than the water tariff chargers, resulting to an amount of RM 0.5979 for the first $35 \mathrm{~m}^{3}$

Another study using the Single-Bound CVM technique was employed by Mahirah, Azlina, Nazirah and Yacob (2015) to estimate the WTP of Klang Valley road users to reduce traffic congestion. The study analysed the data obtained from the 366 respondents to perform the descriptive and logit regression analysis. The dependent variable of the study was in binary form, where $1=$ Yes, and $0=$ No, while both independent variables, namely household income and occupation were found to be significant. A positive coefficient found for income variable implied that higher income resulted in higher WTP. The WTP amount was estimated at RM 1.59 for toll payment in the Klang Valley using the coefficients. 
Azlina, Kamaludiin, and Shwe Sin (2018) used Single-Bound CVM and DoubleBound CVM to estimate the amount used by households in Kuala Terengganu and Kuala Nerus, Terengganu for renewable energy project fund. One of the purposes of the fund was to facilitate the electricity generation from renewable energy project. The necessity for the research was triggered following the present insufficient fund collection, where currently $1.6 \%$ surcharges for monthly electricity usage is being imposed for consumption exceeding $300 \mathrm{kw}$. Hence, the study intended to revalidate the percentage share. A probit regression statistical analysis was conducted involving a total of 411 households collected randomly. The study found that household income influences the WTP for renewable energy project. The estimated WTP value amounts at an average of RM3.22 per month.

\section{International Research Studies of the CVM for Households}

There was a study by Tilahun et al. (2011)2011]. All rights reserved. Readers may make verbatim copies of this document for noncommercial purposes by any means, provided that this copyright notice appears on all such copies. Abstract: Frankincense from Boswellia papyrifera forest (BPF that used the contingent valuation method in the research of the Contingent valuation analysis of rural households' willingness to pay for frankincense forest conservation. This study aimed to identify the factors that determined the rural households' WTP and WTCL for conservation of the BPF and estimated their WTP and WTCL. The results showed that there was a relationship between their willingness to pay and their incomes.

A research was conducted on the willingness to pay river network protection among local residents in Shanghai, China, using the CVM method for estimating the WTP of the local people towards the river networks (Shang et al., 2012). In the results, it was revealed that residents in Shanghai had a high recognition value for the river, but a low degree of satisfaction with the government's action. The study also illustrated that most of the respondents were willing to pay for river network protection with the mean WTP value of $226.44 \mathrm{RMB}$ per household per year.

A study by Amirnejad et al. (2006) had been conducted to estimate the existence value of northern forests in Iran. A total of $65.8 \%$ of the individuals were willing to pay for the existence of the NFI, while about $20 \%$ of these individuals had not yet visited them, and $41 \%$ of them had only visited the NFI once or twice. The mean of the WTP for existence value of these forests was US\$2.51 household/month or an annual value of US\$30.12 for a household.

In terms of the literature gap, willingness to pay studies on forests, per se, are weighted more towards visitors. However, local communities living adjacent to the parks are impacted on, as well, from forest change. Thus, this study contributes towards the present (limited studies) on estimating the value allotted by the local community to the forest using the willingness to donate concept. More so, the application of the willingness to donate concept is still shallow in the body of literature.

\section{Materials and Methods}

\section{Study Area}

The Ayer Keroh Recreational Forest (AKRF) (Figure 3.1) is located in the District of Ayer Keroh, Melaka. This park gives easy access to the public by road from the Malacca Historical City or Bandaraya Bersejarah Melaka. It is about 15 kilometres or about a 20-minute drive from the centre of the city. The total area in the AKRF is 92.5 hectares (Forestry Department of Peninsular Malaysia, 2017).

The AKRF (See Figure 1) is one of the most popular recreational areas among the four (4) located in Melaka, which include the Bukit Batu Lebah Recreational Forest, Sungai Udang Recreational Forest, and Tanjung Tuan Recreational Forest (Forestry Department of Peninsular Malaysia, 2017). The AKRF owned by the Melaka State government is managed by the Forestry Department of Melaka. It was established in 1982 and, since then, 
there have been many developments, such as accommodation, camping areas, jungle trekking areas, and jogging tracks, which are some of the various facilities that are sure to attract the interest of nature lovers. The trees in this park are labelled to facilitate visitors to know the types of plants, and what is more interesting is that the visitors can observe a variety of birds and insects that fly and roam freely there. Another reason for its popularity is its easy accessibility as the forest is connected to the North-South Expressway of Peninsular Malaysia.

Being in a strategic place, the park has been vulnerable to the pressure of development, though not now. Hence, an economic valuation of the park would be beneficial for the future. The WTD is seen as a better technique to encourage the public and households to indicate their valuations of the AKRF. WTD is less stressful than WTP as a donation could imply that an individual must be a direct user of the park. This is because too many people paying may imply that they had gone to the site. For conservation of the resources, one does not have to physically use the resources. Donations may make it less stressful to indicate the value, especially when we ask the households to donate once a year since they live near the AKRF. Hence, donations for conservation may be less stressful. The purpose of asking either the WTP or WTD is to determine the individual's value of the resources. For users who are from other places who may visit only once or not frequently, asking the WTP is feasible since it implies paying only once when they visit the area.

A protected area, a forest, has besides timber (which has a market price) other resources, nontimber products, herbs, watersheds, wildlife, etc., that may not have a market price. WTP or WTD or CVM is used to estimate the value of the biodiversity of the forest resources. The purpose of the estimation is to provide an option value of the forest, a value for future generations. Only with an estimated monetary value can we justify the protection of the forest to provide those various uses as compared to the timber value. Hence, an estimation of the net present value would be useful to compare the value of protecting the area with the value if logging is being carried out now.

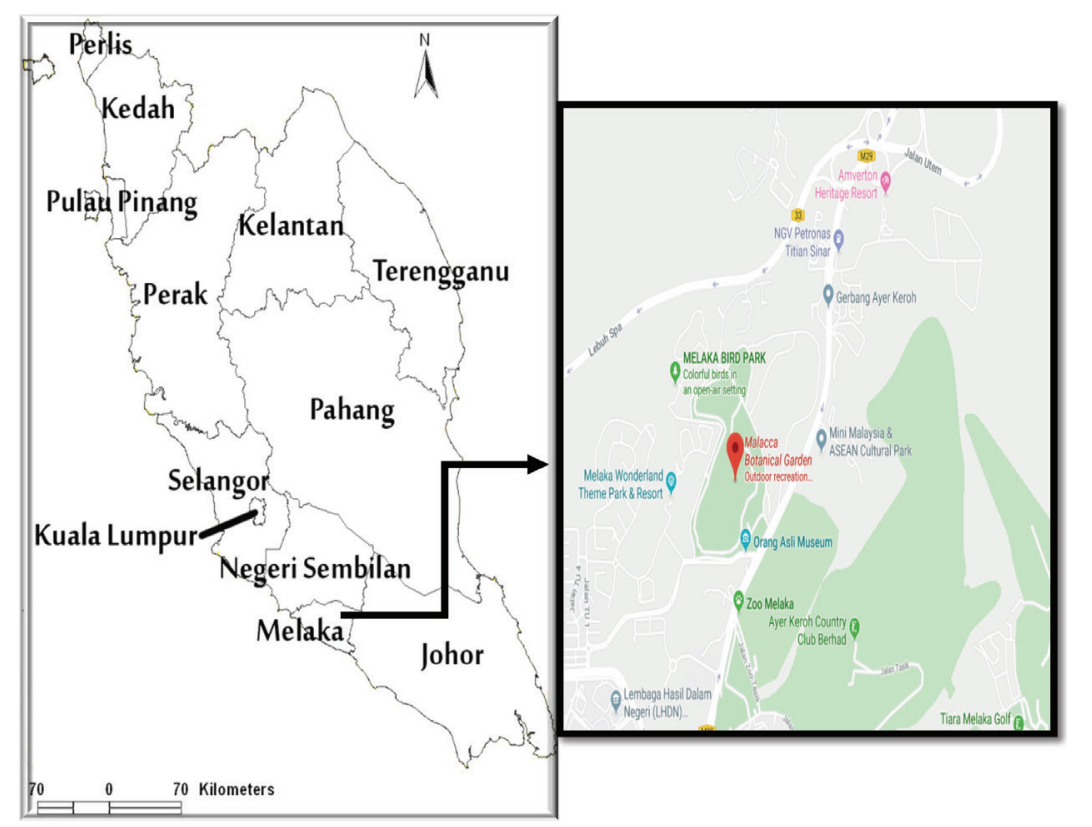

Figure 1: Map location of the Ayer Keroh Recreational Forest in Melaka Source: ArcMAP 10.3 
The Contingent Valuation Method (CVM) is one of the methods used to estimate the economic value of a certain area that involves services and the existing source of nature. This method could be used to estimate the use-value and non-use value. For this method of the CVM, there is the WTP. WTP studies can be conducted using a questionnaire. In a contingent valuation study, there are four types of techniques, namely the bidding game, payment card, open ended, and dichotomous choice (Single-Bound and Double-Bound CVM). In addition, several studies show that the CVM is a good way to determine the conservation values of forest resources (Venkatachalam, 2004).

The focal point of these studies is on how environmental concern influences the WTP for conservation or protection. WTP is a quantitative measure of economic value. On the other hand, WTD is a qualitative measure of the desire or intent to contribute monetarily. Having a willingness to donate is indicative of, and a precursor to, having a positive WTP. Thus, they are related, but not identical concepts (Lee et al., 2018).

\section{Model Specification}

For this study, the probit model was applied to explore the possibility of an individual's willingness to donate for the conservation of the forest resources in the park.

The probit model is as follows:

$$
\begin{aligned}
\mathrm{P}_{\mathrm{i}}= & \mathrm{E}\left(\mathrm{Y}=1 / \mathrm{X}_{\mathrm{i}}\right)=\left[1 /\left\{1+\mathrm{e}^{-\left(\beta+\beta{ }_{\mathrm{i}} \mathrm{X}_{\mathrm{i}}\right\}}\right\}\right] \\
\mathrm{P}_{\mathrm{i}}= & \text { Probability of } \mathrm{Y}=1 \\
\mathrm{X}_{\mathrm{i}}= & \text { A set of independent variables } \\
\beta_{\mathrm{i}}= & \text { Estimated coefficient corresponding to } \\
& \text { logistic distribution }
\end{aligned}
$$

When the natural logarithm was taken from the equation above, it acquired the following equation:

$$
\mathrm{L}_{\mathrm{i}}=\ln \left\{\mathrm{P}_{\mathrm{i}} /\left(1-\mathrm{P}_{\mathrm{i}}\right)\right\}=\beta_{0}+\beta_{\mathrm{i}} \sum \mathrm{X}_{\mathrm{i}}+\mathrm{e}_{\mathrm{i}}
$$

where $L_{i}$ was the probit and was the log of all the odd ratios and linear in both the independent variable and its parameters (Hanemann et al., 1991). The Maximum Likelihood Estimator (MLE) was used as the means of the estimation methods. The logistic regression model has an S-shape distribution function. It simplifies a non-linear transformation of linear regression. The estimation probability is (Hanemann et al., 1991):

$$
p=1 /[1+\exp (-\alpha-\beta X)
$$

where,

$\mathrm{Y}=$ A dummy dependent variable, $=1$ if YES, $=0$ if $\mathrm{NO}$

$\mathrm{P}=$ The probability that the event $\mathrm{Y}$ occurs, $\mathrm{p}$ $(\mathrm{Y}=1)$

$\mathrm{a}=$ The coefficient on the constant term

$\mathrm{b}=$ The coefficient(s) on the independent variable(s)

$\mathrm{X}=$ The independent variable(s)

The following were the variables used in the analysis together with their measurements and descriptions. The initial bid in the table represents the Single-Bound CVM, while the follow-up bid refers to the Double-Bound CVM. The $\varepsilon$ is the random error.

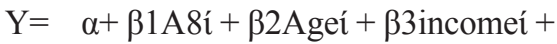

$$
\begin{aligned}
& \beta 4 \text { ownershipí }+\beta \text { InitialBIDí }+ \\
& \beta 6 \text { BID2i }+\varepsilon
\end{aligned}
$$

Where: 
Table 1: Dependent and independent variables

\begin{tabular}{|c|c|c|}
\hline Variables & Type & Description \\
\hline $\mathrm{Y}=$ Willingness to Donate & Categorical & $\begin{array}{l}\text { Dependent variable with } 1 \text { if respondent was willing } \\
\text { to pay for the amount asked from them, } 0 \text { otherwise }\end{array}$ \\
\hline $\begin{array}{l}\text { InitialBID = bid price levels set } \\
\text { out in the CVM question (Di- } \\
\text { chotomous choice format) }\end{array}$ & Continuous & $\begin{array}{l}\text { The amount of the first bid proposed was for RM1, } \\
\text { RM5, RM10, RM15, RM20, and RM25. per year }\end{array}$ \\
\hline Bid2: Follow-up bid assigned & Continuous & $\begin{array}{l}\text { The amount of follow-up bids proposed were for RM1 } \\
\text { (RM0.50/RM5), RM5 (RM 1/RM 10), RM } 10 \text { (RM5/ } \\
\text { RM15), RM15 (RM15/RM25), RM20(RM10/RM20), } \\
\text { and RM 25(RM20/RM30) per year }\end{array}$ \\
\hline $\begin{array}{l}\text { Forest conservation and manage- } \\
\text { ment (A8) }\end{array}$ & Continuous & $\begin{array}{l}\text { Opinion on forest conservation and management } \\
\text { in Likert Scale }\end{array}$ \\
\hline Age & Continuous & Age of the respondents (years) \\
\hline Income & Continuous & Income of the households per month \\
\hline Ownership & Categorical & House ownership of the respondents \\
\hline
\end{tabular}

\section{Questionnaire Design}

The Contingent Valuation Method (CVM) uses survey questions to elicit society's preferences for public goods by creating a hypothetical market. The questionnaire in this study consisted of four parts: A, B, C, and D. Part A provided the general information of the respondents regarding the AKRF. The respondents were asked to state where and how they knew about this park and whether they were related to the current conservation level in the AKRF. Part B provided the respondents' levels of importance for sustainable forest management. Also, the respondents were asked to state why forests need to be managed in a sustainable way. In addition, the respondents were asked to rate their level of agreement by using the Likert scale as follows: 1-Not very important, 2-Not important, 3-Neutral, 4-Important, and 5-Very important. Part $\mathrm{C}$ asked about the evaluation by the households on forest conservation and management by using the Contingent Valuation Method (CVM) to measure the households' willingness to donate for the conservation of the recreational forest. The questions were designed to measure the willingness to donate, and the respondents were asked to use a Dichotomous Choice, in which the respondents could only answer in one of the two indicated ways, such as "A" or "B", Agree or Disagree, True or False, Yes or No, and to quantify the preferences of the households and also their willingness to donate. There were 6 sets of questions in different bids which were divided equally, namely, RM1, RM5, RM10, RM15, RM20, and RM25. Part $\mathrm{D}$ was in regard to the respondents' background information, including the respondents' socioeconomic and demo-graphic characteristics: age, gender, marital status, and education level, and employment sector, number of households, average monthly income, residency, and house ownership. The questionnaire was designed in the Malay language for better comprehension and understanding among the targeted respondents. The preliminary studies were conducted through observations at the site by analysing the real sample. This was to determine the level of understanding and to identify any design error and weakness in the questionnaire.

\section{Test of Validity and Reliability}

Pretesting and a pilot study was conducted to enhance the quality of the constructed questionnaire. The importance of both the pretesting and pilot study was to test the validity and reliability of the questionnaire, to check the wording, clarity of question sequence, and 
timing. The pretesting was conducted on 15 academicians and postgraduate students in Universiti Putra Malaysia to identify whether the questions and responses were valid. From the pretesting, modifications to the questionnaire were made based on the feedback obtained.

Later, a pilot study was conducted on 32 households or $10 \%$ of the required sample for the reliability of the primary data. The responses were later, coded and analysed using the SPSS (Statistical Package for Social Sciences version 25). Questions that did not provide useful data were discarded. The final questionnaire for the research was later finalised. The data were tested for reliability to ensure that the responses to the participation statements were consistent across all the questions or sub-groups of the questions. The data used for the reliability test were the relevant questions that consisted of 14 questions for the perception on the importance of forests, which was measured using the five-point Likertscale. The results showed that the Cronbach's Alpha score was 0.931 for the pilot study and 0.93 for the actual study. A value of more than 0.60 indicated that the scale has better internal consistency and thus was reliable (Sekaran $\&$ Bougie, 2010). Therefore, it indicated that the data was reliable and accepted for further analysis.

\section{Validity Test}

The questions in the questionnaire were validated before the pilot study was conducted. The validators had expertise in the field of social science. The experts who helped in validating the questions were experts in their field.

\section{Sampling Techniques}

Based on the population of 12,014 people (personal communication with the Penghulu Dun Ayer Keroh, Ruslan bin Yusoff, Daerah Ayer Keroh Melaka), the sample size was 313 respondents (Zikmund et al., 2010). The sampling was carried out from July until August 2019 during weekends when household members were available. The seven (7) residencies chosen to participate in the sampling were Ayer Keroh
Heights (4.4 km), Sungai Putat (8.3 km), Taman Kerjasama (8.6 km), Taman Bunga Raya (7.1 $\mathrm{km}$ ), Taman Tasik Utama (3 km), Pulau Samak $(9.7 \mathrm{~km})$, and Kampung Tun Razak $(7.3 \mathrm{~km})$, which were all adjacent to the recreational forest. The respondents were chosen based on convenient sampling on a voluntary basis within the 7 locations. Questionnaires were given to the head of the household. Although 320 samples were collected, only 300 questionnaires with complete answers were used.

\section{Results and Discussion}

\section{Demographic Background of the Local Communities in Ayer Keroh, Melaka}

Table 2 shows the demographic backgrounds of the 300 respondents in the study area. The demographic profiles included gender, age, marital status, education level, employment sector, household size, gross income, period of residence, and home ownership. The target respondents were the villagers and workers who were involved in the study area.

In terms of gender, about $44.3 \%$ (133 respondents) comprised male and the remaining $55.7 \%$ (167 respondents) were female respondents. As for age, it was an important demographic indicator, with most of the respondents being between 18-25 years old (47\%) followed by $26-35$ years old (31\%). Next, the respondents between $36-45$ years old comprised $16.3 \%$ (49 respondents). Meanwhile, 17 of the respondents $(5.7 \%)$ were between 46 55 years old. The age range of the respondents showed that most of them were in the middleaged group. As for marital status, most of the respondents were single $(55.7 \%)$, while $43.7 \%$ of 131 of the respondents were married. There were 2 respondents $(0.7 \%)$ who had stated that their marital status was "other". The education level of the respondents was divided into six categories. Most of the respondents had completed their STPM/diploma (38\%) followed by the respondents who had managed to finish their bachelor's degree (32.2\%). Meanwhile, only 83 respondents $(27.7 \%)$ had finished education at the secondary level. There 
was 1 respondent $(0.3 \%)$ who had a normal education level and no respondent was from the primary school level. There were four types of employment sectors in this questionnaire. A total of 67 respondents $(22.3 \%)$ were selfemployed which was not much different from the government sector which had 23.7\% (71 respondents) and the private sector which had $22.7 \%$ (68 respondents). Only $3.3 \%$ of the respondents were retirees apart from $28 \%$ of the respondents who were from other categories, the majority of which were still students. Half of the respondents $(58.3 \%)$ were categorised as a household size which was comprised of 4-6 persons followed by 1-3 persons which represented $28 \%$. There were 41 respondents $(13.7 \%)$ who had indicated that their household size consisted of 7 people and more. Usually, the income level of respondents is also an important factor that will affect the households' willingness to donate (WTD) for the fee, which is asked of them. Generally, more income implies that they would pay for the conservation fee; but for this study, the level of income did not necessarily indicate a willingness to pay. As shown in Table 4.1, most of the respondents ( 89 or $29.67 \%$ ) earned incomes of RM2000 and below per month. This was followed by incomes of RM2001-RM3000 per month (87 or $29 \%$ ), RM3001-RM4000 per month (51 or 17\%), RM4001-RM5000 per month (44 or $14.67 \%$ ), and above RM5001 (29 or 9.66\%). From the survey conducted, 139 respondents (46.3\%) had lived in the Ayer Keroh area for 1-10 years, followed by 80 respondents $(26.7 \%)$ who had lived there for 11-20 years. Meanwhile, 65 respondents $(21.7 \%)$ had lived there for 21-30 years. Finally, only 16 people $(5.3 \%)$ had lived in Ayer Keroh for 31 years and above.

Table 2: Demographic profiles of the respondents $(n=300)$

\begin{tabular}{lccc}
\hline \multicolumn{1}{c}{ Variables } & Attribute/Value & Number (n) & Percentage (\%) \\
\hline Gender & Male & 133 & 44.3 \\
& Female & 167 & 55.7 \\
\hline Age & $18-25$ years & 141 & 47 \\
& $26-35$ years & 93 & 31 \\
& 36-45 years & 49 & 16.3 \\
& 46 years and above & 17 & 5.7 \\
\hline Marital status & Single & 167 & 55.7 \\
& Married & 131 & 43.7 \\
\hline Education level & Others & 2 & 0.7 \\
& No formal education & 1 & 0.3 \\
& Primary school & 0 & 0 \\
& Secondary school & 83 & 27.7 \\
& STPM/Diploma & 114 & 38.0 \\
& Degree & 97 & 32.3 \\
& Postgraduates & 5 & 1.7 \\
\hline Employment sector & Self-employment & 67 & 22.3 \\
& Government sector & 71 & 23.7 \\
& Private sector & 68 & 22.7 \\
& Retirees & 10 & 3.3 \\
& Others & 84 & 28.0 \\
\hline
\end{tabular}




\begin{tabular}{lccc}
\hline Household size & $1-3$ & 84 & 28 \\
& $4-6$ & 175 & 58.3 \\
& 7 and above & 41 & 13.7 \\
\hline Household income & RM2,000 and below & 89 & 29.67 \\
& RM2,001 - RM3,000 & 87 & 29 \\
& RM3,001 - RM4,000 & 51 & 17 \\
& RM4,001 - RM5,000 & 44 & 14.67 \\
& RM5,001 and above & 29 & 9.66 \\
\hline Period of residency & $1-10$ & 139 & 46.3 \\
& $11-20$ & 80 & 26.7 \\
& $21-30$ & 65 & 21.7 \\
& 31 and above & 16 & 5.3 \\
\hline
\end{tabular}

As shown in Table 3, most of the respondents were familiar with the AKRF because they had visited the area before (154 respondents or 51.3\%). Meanwhile, 76 respondents were familiar with the AKRF's area because they had lived in or near this area. There were 70 respondents who had never visited the AKRF before. A total of 199 respondents concurred that the tax collected by the government would be used for protecting the AKRF area, whereas 101 respondents did not agree with this statement. About 292 respondents agreed with the statement that enhancing conservation and management of the
AKRF was a good idea, while 8 respondents did not agree with this fact.

\section{The Importance of the Forest in the Ayer Keroh Recreational Forest}

The average overall perception of the importance of the forest in the AKRF was shown in Table 4 above. The respondents thought that the forest in the AKRF was important as the green-lung area with a value of 4.50 and an increase in water quality at 4.41 . This was followed by an increase in air quality (4.53), as a water catchment (4.33), wildlife habitat improvement (4.35), and as a

Table 3: AKRF in general

\begin{tabular}{lcc}
\hline \multicolumn{1}{c}{ Statement } & Frequency & Per cent \\
\hline Familiarity with the AKRF's area & & \\
1) I live in or near this area. & 76 & 25.3 \\
2) I have visited this area before. & 154 & 51.3 \\
3) I have not visited this area before. & 70 & 23.3 \\
Protect the AKRF using taxes collected & & \\
Yes & 199 & 66.3 \\
No & 101 & 33.7 \\
Opinion on how to improve conservation & & \\
and management & 292 & 97.3 \\
Yes & 8 & 2.7 \\
No & & \\
\hline
\end{tabular}


site for scientific education and research (4.41). Besides that, the average importance of the forest in the AKRF for highlighting the beauty of nature was 4.55 , provided unique plant habitats, ecosystems, and genetic resources at 4.51, and as recreation and ecotourism at 4.52. The average for environmental education activities and reducing the incidence of floods were the same at 4.54. Finally, the average importance of the forest in the AKRF for the next generation's usage was 4.60 and for sustainable benefits by the residents, it was 4.57. Approximately $85.3 \%$ from the 300 respondents knew that the AKRF area is one of the most important ecosystems for flora and fauna habitat, source of food, ecotourism area, recreation, and others; although, $14.7 \%$ from the 300 respondents did not think so. The overall mean of the perception of the importance of the AKRF for households was 4.49 , which was strongly agreeable. This result is in line with a study conducted in Uganda by Bamwesigye, et al. (2020), which illustrated that around 82 per cent of the sample of residents was willing to pay for forest conservation and sustainability. They also argued that willingness to pay for forest conservation was significantly correlated with the locals' preferences for forest values and sustainability.

For a Five-Point Likert Scale: use the formula: (Highest value - lowest)/ No. of categories in statistical calculation: levels is $=(5-1) / 3: 1.333$, hence the first level: low (1) will start from (1+1.333) 1- 2.339, Medium (2): 2.34-3.669, and High (3): 3.67-5.00.

\section{Probit Regression Analysis}

For the analysis in Table 5, the pseudo $\mathrm{R}^{2}$ was 0.0972 for the Single-Bound CVM, which indicates that $9.72 \%$ of the variance in the dependent variable was explained by the independent variables in the model, whereas

Table 4: The importance of the AKRF

\begin{tabular}{lcccccccc}
\hline \multirow{2}{*}{ Variables } & \multicolumn{9}{c}{ Degree of } & \multicolumn{1}{c}{ Importance (\%) } & Mean & Levels \\
\cline { 2 - 7 } & $\mathbf{1}$ & $\mathbf{2}$ & $\mathbf{3}$ & $\mathbf{4}$ & $\mathbf{5}$ & & \\
\hline As a green-lung area & 0 & 0 & 5.7 & 38.3 & 56.0 & 4.50 & 3 \\
Increase water quality & 0.3 & 0.3 & 8.7 & 39.3 & 51.3 & 4.41 & 3 \\
Increase air quality & 0 & 0.3 & 5.7 & 34.7 & 59.3 & 4.53 & 3 \\
Temperature reduction & 0 & 0 & 7.3 & 34.0 & 58.7 & 4.51 & 3 \\
As a water catchment & 0.3 & 2.3 & 13.3 & 32.0 & 52.0 & 4.33 & 3 \\
Wildlife habitat improvement & 0.3 & 1.0 & 14.0 & 32.7 & 52.0 & 4.35 & 3 \\
As a site for scientific educa- & 0 & 0.7 & 14.0 & 29.3 & 56.0 & 4.41 & 3 \\
tion and research & & & & & & & \\
Highlight the beauty of nature & 0 & 0 & 6.7 & 31.7 & 61.7 & 4.55 & 3 \\
Provide unique plant habi- & 0 & 0.3 & 7.7 & 32.7 & 59.3 & 4.51 & 3 \\
tats, ecosystems, and genetic & & & & & & & \\
resources & & & & & & & \\
As recreation and ecotourism & 0.7 & 0 & 8.7 & 28.0 & 62.7 & 4.52 & 3 \\
For environmental education & 0 & 0.3 & 7.7 & 29.7 & 62.3 & 4.54 & 3 \\
activities & & & & & & & \\
Reduce the incidence of floods & 0.3 & 0.3 & 8.3 & 27.3 & 63.7 & 4.54 & 3 \\
For next the generation's usage & 0 & 0 & 6.0 & 27.2 & 66.3 & 4.60 & 3 \\
Sustainable benefits for resi- & 0.3 & 0.3 & 6.7 & 27.0 & 65.7 & 4.57 & 3 \\
dents & & & & & & & \\
\hline Overall Mean & & & & & & $\mathbf{4} .49$ & $\mathbf{3}$ \\
\hline
\end{tabular}


for the Double-Bound CVM it was found to be greater at $17.22 \%$. A large Pseudo $\mathrm{R}^{2}$ value indicates a better model fit, where McFadden's pseudo R-squared value, ranging from 0.2 to 0.4 , indicates a very good model fit (Thalany, 2014). Hence, the Pseudo $\mathrm{R}^{2}$ value for the DoubleBound CVM (0.17) was approximately good.

Hence, the following discussions are based on the latter. For the Double-Bound CVM, out of all the five variables tested, only 3 were found to be significant, which were age, income, and A8 (improve conservation and management). It was noted that for the Double-Bound CVM, although bid 1 and bid 2 were integrated in the model, it did not appear in the analysis as witnessed in the table (Lopez-Feldman, 2012). However, since the Double-Bound CVM is an extension of the Single-Bound CVM, the Bid variable can be explained. The negative coefficient found for the BID1 variable (-.0368257) was consistent with the demand theory. This is where the higher the bid price, the lower the WTP.

For variable A8, a positive coefficient implied an inverse relationship with the willingness to donate. Thus, the higher the perception towards the importance to conserve and manage the recreational forest, the higher the WTD. The result is consistent with Azhari and Mohamed (2012). They found that the level of perception and sensitiveness of the Malaysian public on green area conservation in Bukit Nanas, Kuala Lumpur was positively related to their willingness to donate. The age variable showed a negative relationship to the WTD, thus, households who were younger had a greater value towards the recreational forest. A study by Valkó and Csete (2008) showed that younger people presented higher ratios of willingness to pay for environmentally friendly products to preserve the environment.

On the other hand, for income variables, a positive coefficient value suggested that the higher the household income, the greater the WTD for forest conservation and management.

This conclusion is supported by another study, which illustrated that forest service type and income significantly influenced participants' willingness to pay for forest conservation (AlAssaf., 2015).

\section{Estimation of the WTD}

Table 6 shows the estimation of the WTD value. The syntax here was adapted from Lopez-Feldman (2012). The syntax used for

Table 5: Single-bound and double-bound CVM

\begin{tabular}{|c|c|c|c|c|c|c|c|}
\hline \multicolumn{4}{|c|}{ Single-Bound CVM } & \multicolumn{4}{|c|}{ Double-Bound CVM } \\
\hline & Coefficient & $\begin{array}{c}\text { Standard } \\
\text { Error }\end{array}$ & Significant & & Coefficient & $\begin{array}{l}\text { Standard } \\
\text { Error }\end{array}$ & Significant \\
\hline BID1 & -.0368257 & .0097868 & $0.000 * * *$ & & & & \\
\hline A8 & .8800453 & .4835474 & $0.069 * * *$ & A8 & 20.15575 & 5.918835 & $0.001 * * *$ \\
\hline Age & -.0255379 & .0093579 & $0.006 * * *$ & Age & -.1817672 & .1028815 & $0.077^{*}$ \\
\hline Income & .0001173 & .000053 & $0.027 * * *$ & Income & .0011195 & .0006057 & $0.065^{*}$ \\
\hline Ownership & -.3506181 & .1721698 & $0.042 * * *$ & & & & \\
\hline $\mathrm{R}^{2}$ & 9.72 & & & $\begin{array}{l}\text { Wald } \\
\text { chi2(3) }\end{array}$ & 17.22 & & \\
\hline
\end{tabular}

Table 6: Estimation of the willingness to donate

\begin{tabular}{cccccc}
\hline & Single-Bound CVM & \multicolumn{3}{c}{ Double-Bound CVM } \\
\hline Coefficient & $\begin{array}{c}\text { Standard } \\
\text { Error }\end{array}$ & Significant & Coefficient & $\begin{array}{c}\text { Standard } \\
\text { Error }\end{array}$ & Significant \\
\hline 22.41572 & 3.173736 & $0.000^{* * *}$ & 17.74455 & .9254526 & $0.000^{* * *}$ \\
\hline
\end{tabular}


calculating the effects of the variables was found to be significant in the previous probit regression analysis. The results revealed that the WTD estimation based on the Double-Bound CVM (RM 17.74) was found to be lower than the Single-Bound CVM (RM22.42) and both were significant at $99 \%$ levels of confidence. Hence, following the best model with the higher R-square, the WTD estimation based on the Double-Bound CVM was proposed in this study to policymakers.

\section{Conclusion}

The aim of this paper was to investigate households' willingness to donate for the conservation and management of the Ayer Keroh Recreational Forest in Melaka. The results indicated that the idea of enhancing conservation efforts, age, and income had a significant relationship with the willingness to donate. Estimation on the willingness to donate using the Double-Bound CVM amounted to RM17.74 per household per annum. Approximately $85.3 \%$ from 300 respondents were aware that the AKRF area is one of the most important ecosystems for flora and fauna habitat, source of food, ecotourism area, recreation, and others.

Furthermore, the results showed that respondents who had higher perception levels towards the importance to conserve and manage the recreational forest had a higher willingness to donate. The age variable showed a negative relationship with the willingness to donate. Thus, younger households value the recreational forest more. On the other hand, a positive coefficient value of income suggested that households with higher incomes had a greater willingness to donate for forest conservation and management. The findings further suggested that the house ownership of the respondents could negatively influence the willingness to donate for the conservation and management of the Ayer Keroh Recreational Forest in Melaka.

Further research would be necessary to validate the results of the WTD estimates in this study. It would be remarkable to test the significance of the study location, Melaka, by carrying out a survey in other areas with similar socio-economic characteristics. Additionally, it would be beneficial to solicit preferences for tropical forest conservation by using alternative research methodologies to assess the potential effects of research bias. Respondents' sociodemographic profile plays an important role in determining the willingness to pay. However, the different demographics may differently influence respondents' willingness to pay. This study also illustrated that in undertaking efforts to conserve the recreational forest ecosystems, it is important to have the support of the communities that most depend on the forests. Residents living adjacent to the park represent such a community.

The findings of the current study have several policy implications. First the participants' perceptions of the importance of forest conservation need to be of concern. National funding is probably needed to increase the Malaysian public's awareness of the importance of natural resources. Such support is likely to promote more domestic endeavours and contributions to forest preservation. Moreover, educating the younger generation will have significant influence on the willingness to preserve the environment and, specifically, forest conservation in Malaysia. Finally, increasing local awareness about the benefits of biodiversity and forest conservation can effectively encourage them to safeguard the natural resources and should be considered by Malaysian policymakers and the government.

\section{Acknowledgements}

This research was funded by the Research Management Centre, Universiti Putra Malaysia, Serdang under the GP-IPM/2019/9675100.

\section{References}

Afroz, R., \& Masud, M. M. (2011). Using a contingent valuation approach for improved solid waste management facility: Evidence 
from Kuala Lumpur, Malaysia. Waste Management, 31(4), 800-808.

Afroz, R., Morshed, N., Muhibbullah, M., Duasa, J., \& Khalid, H. (2019). Willingness to pay of the households for Solar Energy-A case study in Kuala Lumpur Malaysia. International Conference on Economic, Entrepreneurship and Management, Langkawi, Malaysia.

Amirnejad, H., Khalilian, S., Assareh, M. H., \& Ahmadian, M. (2006). Estimating the existence value of north forests of Iran by using a contingent valuation method. Ecological Economics, 58(4), 665-675.

Al-Assaf, A. A. (2015). Applying contingent valuation to measure the economic value of forest services: A case study in Northern Jordan. International Journal of Sustainable Development \& World Ecology, 22(3), 242250.

Azhari, N. F. N., \& Mohamed, E. (2012). Public perception: Heritage building conservation in Kuala Lumpur. Procedia-Social and Behavioural Sciences, 50, 271-279.

Azlina, A. A., Kamaludin, M., \& Sin, M. S. (2018). Willingness to pay for renewable energy: Evidence from Malaysian's households. Jurnal Ekonomi Malaysia, 52(3), 143-151.

Bakaki, Z., \& Bernauer, T. (2016). Measuring and explaining the willingness to pay for forest conservation: Evidence from a survey experiment in Brazil. Environmental Research Letters, 11(11), 114001. https:// doi.org/10.1088/1748-9326/11/11/114001.

Bamwesigye, D., Hlavackova, P., Sujova, A., Fialova, J., \& Kupec, P. (2020). Willingness to pay for forest existence value and sustainability. Sustainability, 12(3), 891.

Chen, B., Nakama, Y., \& Zhang, Y. (2017). Traditional village forest landscapes: Tourists' attitudes and preferences for conservation. Tourism Management, 59, 652-662. https://doi.org/10.1016/j. tourman.2016.09.007.
Cheung, L. T., \& Hui, D. L. (2018). Influence of residents' place attachment on heritage forest conservation awareness in a periurban area of Guangzhou, China. Urban Forestry \& Urban Greening 33, 37-45. https://doi.org/10.1016/j.ufug.2018.05.004

Cubbage, F., Harou, P., \& Sills, E. (2007). Policy instruments to enhance multi-functional forest management. Forest Policy and Economics, 9(7), 833-851. https://doi. org/10.1016/j.forpol.2006.03.010

Forestry Department of Peninsular Malaysia. (2017). Total area in Ayer Keroh Recreational Forest, Melaka. Retrieved July 5, 2019, from http://www.forestry.gov. my

Hanemann, M., Loomis, J., \& Kanninen, B. (1991). Statistical efficiency of double bounded dichotomous choice contingent valuation. American Journal of Agricultural Economics, 73(4), 1255-1263.

Ismail, S. M., \& Rahman, A. A. (2010). The need for pricing policy for forest recreation areas as ecotourism destination. Prosiding Persidangan Kebangsaan Penilaian Ekonomi Sumber Hutan.

Kamaludin, M., Radam, A., Rahim, K. A., \& Yacob, M. R. (2013). Consumer willingness to pay for domestic water services in Kelantan. VOL. 21 (S) SEPT. 2013, 1.

Lee, W. S., \& Moon, J. (2018). Examination of loss aversion and its role in willingness to pay for leisure services using the Contingent Valuation Method. Journal of Quality Assurance in Hospitality \& Tourism, 19(1), 31-44.

Leong, P. C., Zakaria, M., Ghani, A. N. A., \& Mohd, A. (2005). Contingent valuation of a Malaysian Highland Forest: Non-market benefits accrued to local residents. Journal of Applied Sciences, 5(5), 916-919.

Lopez-Feldman, A. (2012). Introduction to contingent valuation using stata. MPRA Paper No. 41018. Toluca, Mexico: Centro 
de Investigacion y Docencia Economicas (CIDE).

Mahirah, K., Azlina, A. A., Nazirah, I., \& Yacob, R. (2015). Valuing road user's willingness to pay to reduce traffic congestion in Klang Valley, Malaysia. Asian Social Science, 11(25), 48.

Masahina, S., Afroz, R., Duasa, J., \& Mohamed, N. (2012). A framework to estimate the willingness to pay of household for air quality improvement: A case study in Klang Valley, Malaysia. OIDA International Journal of Sustainable Development, 4(9), 11-16.

Rahman, A. A. (2007). Consumers'satisfaction towards recreational facilities and services in Ayer Keroh Forest Recreational Area, Melaka (Doctoral dissertation). Universiti Putra Malaysia.

Ramli, F., Samdin, Z., \& Ghani, A. (2017). Willingness to pay for conservation fee using contingent valuation method: The case of Matang Mangrove Forest Reserve, Perak, Malaysia. Malaysian Forester, 80(1), 99-110.

Samdin, Z. (2008). Willingness to pay in Taman Negara: A contingent valuation method. International Journal of Economics and Management, 2(1), 81-94.

Scheyvens, R. (1999). Ecotourism and the empowerment of local communities. Tourism Management, 20(2), 245$249 . \quad$ https://doi.org/10.1016/S02615177(98)00069-7.

Sekaran, U., \& Bougie, R. (2010). Research methods for business: A skill building approaches (5th ed.). Chichester, West Sussex: John Wiley \& Sons, Inc.

Shang, Z., Che, Y., Yang, K., \& Jiang, Y. (2012). Assessing local communities' willingness to pay for river network protection: A contingent valuation study of Shanghai, China. International Journal of Environmental Research and Public Health, 9(11), 3866-3882.
Thalany, K. (2014). Economic values of conservation and management attributes in Bako National Park, Sarawak, Malaysia. Unpublished doctoral dissertation, Universiti Putra Malaysia, Selangor.

Tilahun, M., Mathijs, E., Muys, B., Vranken, L., Deckers, J. A., Gebregziabher, K., \& Bauer, H. (2011). Contingent valuation analysis of rural households' willingness to pay for frankincense forest conservation (No. 7262016-50026).

Valkó, L., \& Csete, M. (2008). Sustainable consumption. Periodica Oeconomica. Regional Development and Competitveness. Edited by Michel Carmona, János Szlávik, Éva Zám. Eger. Lectored by Professor J. Markham Collins. University of ParisSorbonne IV-Eszterházy Károly College, 93-103.

Venkatachalam, L. (2004). The contingent valuation method: A review. Environmental Impact Assessment Review, 24(1), 89-124.

Wilkes, Allemann, J., Pütz, M., \& Hirschi, C. (2015). Governance of forest recreation in urban areas: Analysing the role of stakeholders and institutions using the institutional analysis and development framework. Environmental Policy and Governance, 25(2), 139-156.

Yacob, M. R., Radam, A., Shuib, A., Samarahan, K., \& Sarawak, M. (2009). A contingent valuation study of marine parks ecotourism: The case of Pulau Payar and Pulau Redang in Malaysia. Journal of Sustainable Development, 2(2), 95-105. https://doi. org/10.5539/jsd.v2n2p95.

Zikmund, W. G., Babin, B. J., Carr, J. C., \& Griffin, M. (2010). Business research methods (8th ed.). Canada: South Western Cengage Learning. 